\title{
Comparative Analysis of Five Heliotropium species in Phenotypic Correlations, Biochemical Constituents and Antioxidant Properties
}

\author{
Deya El-deen M.Radwan ${ }^{1,2}$, Ahmed E. El-shabasy ${ }^{1}$ \\ ${ }^{1}$ Biology Department, Faculty of Science, Jazan University, KSA \\ 2. Botany Department, Faculty of Science, Sohag University, Egypt
}

\begin{abstract}
This study aims to compare five species of Heliotropium collected from Jazan region, Kingdom of Saudi Arabia. This comparison was carried out on basis of morphology, pigments content, proteins, total phenolics, flavonoids as well as their antioxidant activity. According to similarity matrix and cluster analysis, $H$. longiflorum and $H$. zeylanicum were closely related while $H$. pterocarpum and $H$. zeylanicum were distantly related species. The variation in pigments content of the five studied species of Heliotropium was obvious. $H$. zeylanicum recorded the highest content of pigments while $H$. bacciferum was the lowest. Moreover, $H$. jizanense and $H$. pterocarpum had almost similar pigments content. Proteins, phenolics and flavonoids showed noticeable variation among the tested species. In other words, H. zeylanicum and $H$. bacciferum had the highest contents of proteins, phenolics and flavonoids and $H$. jizanense had lowest and the difference was significant. Meanwhile, the total antioxidant activity was variable among species. Higher antioxidant activity was detected in $H$. zeylanicum (93\%) and $H$. bacciferum (84\%) while $H$. pterocarpum $(34.5 \%)$.
\end{abstract}

Keywords: Heliotropium, Boraginaceae, pigments content, proteins content, phenolic compounds, flavonoids, antioxidant activity.

\section{INTRODUCTION}

Heliotropium with its different species is considered as valuable medicinal plant worldwide. Genus Heliotropium belongs to Boraginaceae s.l., a large family of dicotyledonous angiosperms which includes 16 genera and 170 species present in the Mediterranean basin and Middle East and extending through Europe and Tropical Africa (Selvi and Bigazzi 2001). The name "heliotrope" comes from the fact that these plants turn their leaves to the sun. Heliotropium L. is commonly used in wounds, flatulence, inflammation, skin ulcers and conjunctivitis (Ogbole et al., 2018). It is considered as a paraphyletic taxon. Helotropium L. is a large genus which consists of about 250-300 species all over the world. These species are distributed in tropical and temperate regions. There are strong resemblances on the morphological characteristics. Previously, many authors investigated the taxonomic importance of reproductive char-acteristics in the taxonomy of Helioropium (Naggar et al., 2015). Species of Heliotropium exhibit great polymorphism that makes them hard to identify their number accurately. The south western region of the Arabian Peninsula is considered as a part of the floristic hotspot where there are many genera have not been got proper attention like Heliotropium L. (Myers et al., 2000). Heliotropium species were poorly investigated under the wide-scoped floristic studies of the Arabian Peninsula.

Biochemical constituents of plants such as pigments, proteins and plant secondary products are used to differentiate and compare between species belonging to the same genus. Chlorophylls are antioxidants present in different forms; Chlorophyll a and Chlorophyll b, they are considered essential pigments in the plant. Variation in leaf chlorophyll content can provide information about the physiological condition of a leaf or plant (Richardson et al., 2002). Different plant species even if belong to the same genus have different characteristics because of variation in content and type of pigments; chlorophyll, carotenoids, other pigments which together constitute the spectral characters of a plant body. It is necessary to do such study to compare the contents of pigments between the collected Heliotropium species for differentiation on basis of biochemical macromolecules. Plant proteins are cellular functional macromolecules which are required to perform wide range of functions as enzymatic activities and managing transport across cellular membranes. The variation in protein content present in different species which belong to the same genus was previously reported (Trugo et al., 2003). For example, it was found that wild and cultivated species of Echinocloa millets contain different contents of proteins and amino acids. Most of the medicinal value of the plant was related to its content of phenolic compounds. Similar to proteins content, analysis of phenolic was used to differentiate several species of Acacia (Gabr et al., 2018). Moreover, differences in phenolic compounds in six species of Eucalyptus were observed (Santos et al., 2008). It was reported, different species of the Heliotropium produce a resinous exudate that covers their leaves and stems. These exudates are composed mainly of flavonoids (Modak et al., 2005). Moreover, the resinous exudates were reported to have antioxidant behavior. Studies done by Lissi et al., (1999) on antioxidant evaluation of different Heliotropium species showed different antioxidant activities related to amounts of antioxidants and their reactivity against free radicals. In this work, the studied species were Heliotropium backiferum Forssk, Heliotropium jizanense Al-Turki; Omar \& Ghafoor, Bot. Jour. Linn. Soc., Heliotropium longiflorum Steud. \& Hochst. ex Bunge. DC. Prodr., Heliotropium pterocarpum (DC.) Steud. \& Hochst. ex Bunge. DC. Prodr. And Heliotropium zeylanicum (Burm.f.) Lam., Encl.

The studied area is located in the Jazan province which is situated in the south western part of Saudi 
Arabia at $16^{\circ} 20^{\prime} \mathrm{N}, 42^{\circ} 45^{\prime} \mathrm{E}$. It extended from Al-Tuwal region in the south to Wadi Lejib in the north. The Jazan province has many wadis which formed by the deposition of silt coming from the flash floods which flow the low banks of wadis. The wadis have a mean annual rain fall of $7.4 \mathrm{~m} 3 / \mathrm{Sec}$. The vegetation is near the foot-hills where are generally dry with deposits of silt and sand (Ahmed et al., 2005).

This study aims to compare the five collected species of Heliotropium L. on basis of their morphological characteristics, biochemical constituents as well as antioxidant activity.

\section{MATERIALS AND METHOD}

\section{Collection of plant material and preparation}

Freshly whole plant samples of Heliotropium species; $H$. bacciferum, $H$. jizanense, $H$. longiflorum, $H$. pterocarpum and $H$. zeylanicum were collected from Jazan province, Kingdom of Saudi Arabia during March 2018 (Table 1) (Figure1) (Coordinates from maps of Saudi Survey Authority). They were identified by the herbarium of the Biology Department, Faculty of Science, Jazan University (JAZUH) (Dr. Remesh Mockickel). They were washed thoroughly 2-3 times with running tap water and then once with sterile water, dried in the sun and followed by drying at $65^{\circ} \mathrm{C}$ for $48 \mathrm{hrs}$, subsequently ground into fine powder. This powder was used to extract soluble and total proteins. For phenolics and flavonoids and antioxidant activity analyses, 100 grams of plant powder were extracted in $250 \mathrm{ml}$ methanol in Soxhlet apparatus at $60^{\circ} \mathrm{C}$ for $4 \mathrm{~h}$ continuously and the solvent was let to evaporate in bakers. Percentage yield was calculated from the formula:

$$
\% \text { Yield }=\frac{\text { weight dried extract }}{\text { weight of seed powder }} \times 100
$$

The remaining crude materials were weighed and dissolved in methanol to be used in evaluation of antioxidant properties.

\section{Scoring of data and cluster analysis}

The morphological characters and Phytochemical traits are scored to form phenetic analysis to the studied species of Heliotropium L. Similarity matrix and cluster analysis were constructed by using Pclass (ElGazzar and Rabei 2008), where distances were calculated using a modification of the Gower coefficient (Gower 1982). Sequential agglomerative, hierarchic nest clustering was done with UPGMA.

\section{Analysis of pigments content}

According to method of Lichtenthaler and Buschmann (Lichtenthaler and Buschmann 2001), Leaf samples of the 5 species of Heliotropium were collected and then meshed using acetone $90 \%$ in dim light conditions using a mortar. The extracted solution was then transferred to be centrifuged for $20 \mathrm{~min}$ at 4000 rpm. The supernatant was then used for colorimetric determination of pigments by recording the absorbance at wavelengths 663, 647, $470 \mathrm{~nm}$. Acetone $90 \%$ solution was used as blank.
The pigments contents were then calculated using the following formulas:

Chl. $\mathrm{a}=12.25$ A663 - 2.79 A647

Chl $. \mathrm{b}=21.50 \mathrm{~A} 647-5.10 \mathrm{~A} 663$

Carotenoids $=(1000$ A470 $-1.82 *$ Chl. a $-95.151 *$ Chl . b) $/ 225$

\section{Analysis of proteins content}

The contents of soluble, insoluble and total proteins for the 5 collected species of Heliotropium were analysed by Lowery method (Lowery). Dry leaf tissue samples were extracted in distilled water for determination of soluble proteins and extracted in $0.1 \% \mathrm{NaOH}$ for total protein analysis. The used reagent is alkaline which composed of [Reagent $\mathrm{A}\left(2 \% \mathrm{Na}_{2} \mathrm{CO}_{3}\right.$ in $0.1 \mathrm{~N}$ $\mathrm{NaOH})$ and Reagent $\mathrm{B}\left(0.5 \% \mathrm{CuSO}_{4}\right.$ in $1 \%$ sodium potassium tartrate)]. After mixing $1 \mathrm{ml}$ sample with $5 \mathrm{ml}$ reagent and kept standing for 20min, $0.5 \mathrm{ml}$ Folin Ciocalteau reagent (1:1) is added. The blue color was developed after $5 \mathrm{~min}$ and then the absorption was analysed at $700 \mathrm{~nm}$ using UV-VIS spectrophotometer (T80, PG Instruments, UK).

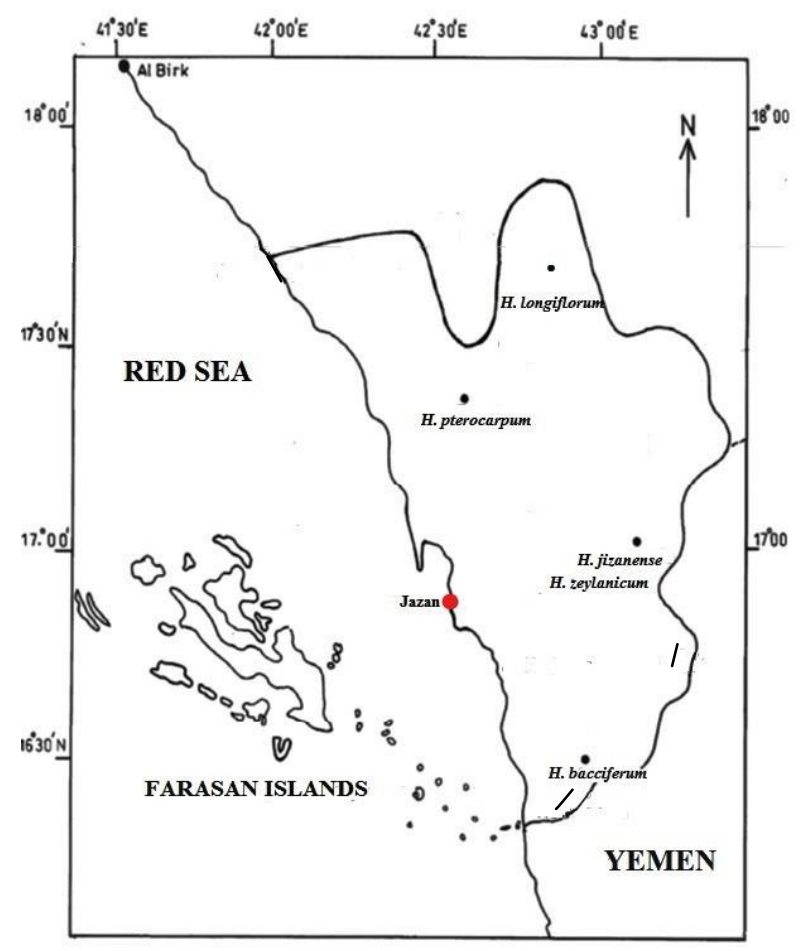

Figure (1): Map of the studied area.

\section{Analysis of total phenolic compounds}

To compare the total contents of phenolic compounds detected in the collected Heliotropium species, the method described by was used. Powdered tissue of the plants was extracted in methanol and $0.2 \mathrm{ml}$ from each extract was mixed with $1.8 \mathrm{ml}$ diluted Folin Ciocalteau reagent $(1: 1)$. The mixture was left to stand for $5 \mathrm{~min}$ before adding $1.2 \mathrm{ml}$ of $\mathrm{NaHCO}_{3}(7.5 \%)$ and mixed vigorously then left for $60 \mathrm{~min}$. The developed blue color was then analysed at 765 against relevant blank. Gallic acid was used to make a standard curve and the results were expressed as gallic acid equivalents (GAE)/g tissue. 
Table (1): Coordination and location of Heliotropium species collected.

\begin{tabular}{lll}
\hline \hline \multicolumn{1}{c}{ Species } & $\begin{array}{c}\text { CollectingCoordinates } \\
\text { (Lat. N, long. E) }\end{array}$ & \multicolumn{1}{c}{ Locality } \\
\hline Heliotropium bacciferum & $16^{\circ} 30^{\prime} \mathrm{N} 42^{\circ} 55^{\prime} \mathrm{E}$ & Al-Tuwal \\
Heliotropium jizanense & $17^{\circ} 05^{\prime} \mathrm{N} 43^{\circ} 05^{\prime} \mathrm{E}$ & Wadi Al-Abadil \\
Heliotropium longiflorum & $17^{\circ} 40^{\prime} \mathrm{N} 42^{\circ} 55^{\prime} \mathrm{E}$ & Wadi Lejib \\
Heliotropiumpterocarpum & $17^{\circ} 20^{\prime} \mathrm{N} 42^{\circ} 35^{\prime} \mathrm{E}$ & Wadi Baysh \\
Heliotropium zeylanicum & $17^{\circ} 05^{\prime} \mathrm{N} 43^{\circ} 05^{\prime} \mathrm{E}$ & Wadi Al-Abadil \\
\hline \hline
\end{tabular}

\section{Analysis of total Flavonoids}

The method of Dewanto et al., (2002) was used to detect the amount of total flavonoids in different Heliotropium species. The powder of dried Heliotropium samples was extracted in methanol and then mixed with $75 \mu \mathrm{l} \mathrm{NaNO}_{2}(5 \%)$ and then left standing for $7 \mathrm{~min}$. The previously prepared solution was mixed with $150 \mu \mathrm{l}$ of $\mathrm{AlCl}_{3}(10 \%)$ and $0.5 \mathrm{~mL}$ of $\mathrm{NaOH}(1 \mathrm{M})$ to the. Complete the mixture to be $2.5 \mathrm{ml}$ volume with dist. $\mathrm{H}_{2} \mathrm{O}$. The developed color was analysed against blank at $510 \mathrm{~nm}$. A standard curve was done using catechin and the results were calculated and expressed as $\mu \mathrm{g}$ catechin equivalents per gram of dry weight.

\section{Analysis of total antioxidant activity}

Using DPPH scavenging assay described by Shimada et al., (1992), the total antioxidant activity of different Heliotropium species were determined. Methanolic plant extracts were mixed with the same volume of freshly prepared solution (80 ppm in methanol) of 1 , 1-diphenyl-2-picrylhydrazyl (DPPH). The mixed components were shacked and kept in dark conditions for $30 \mathrm{~min}$ and then the absorption was analysed at $517 \mathrm{~nm}$ against blank. The lower absorbance means higher scavenging activity. The percentage of DPPH scavenging activity was calculated as follows:

DPPH scavenging ability $(\%)=[1-(\mathrm{Ai}-\mathrm{Aj}) / \mathrm{Ac}] \times$ 100

$\mathrm{Ai}$ is absorbance of extract $+\mathrm{DPPH}, \mathrm{Aj}$ is absorbance of extract + methanol, and Ac is absorbance of DPPH + methanol

\section{Statistical analysis}

Results were tested for significance by using Duncan's range test (Duncan, 1951). This test was to evaluate the differences among species. Statistical tests were carried out using SPSS software (ver. 22) for Windows.

\section{RESULTS}

\section{The morphological characteristics}

The morphological characters of studied plant species besides photochemical analysis were presented as a binary matrix (0) and (1). This binary matrix was analyzed using 'SIMQUAL' sub-program and NTSYSpc version $2.11 \mathrm{w}$ software to calculate the similarity values and generate the phenogram. The Nei genetic similarity index (SI) was utilized for estimating the pairwise similarity between the operational taxonomic units (OTUs) on the basis of the equation, $\mathrm{SI}=2 \mathrm{Nij}$ / $(\mathrm{Ni}+\mathrm{Nj})$, where $\mathrm{Nij}$ is the number of common characters shared between species $\mathrm{i}$ and $\mathrm{j}, \mathrm{Ni}$ and $\mathrm{Nj}$ are the total number of characters for species $i$ and $j$, respectively (Table 2\&3). After obtaining the similarity matrix, clustering was performed by a distance based method of sequential agglomerative hierarchical nested clustering where series of successive mergers are used to group species with similar characteristics. The graphical representation of the cluster (phenogram) was obtained by using 'SAHN' sub-program of NTS-YSPC software; the unweight pair group method of mathematical averages (UPGMA) (Yao et al., 2007) (Figure 2).

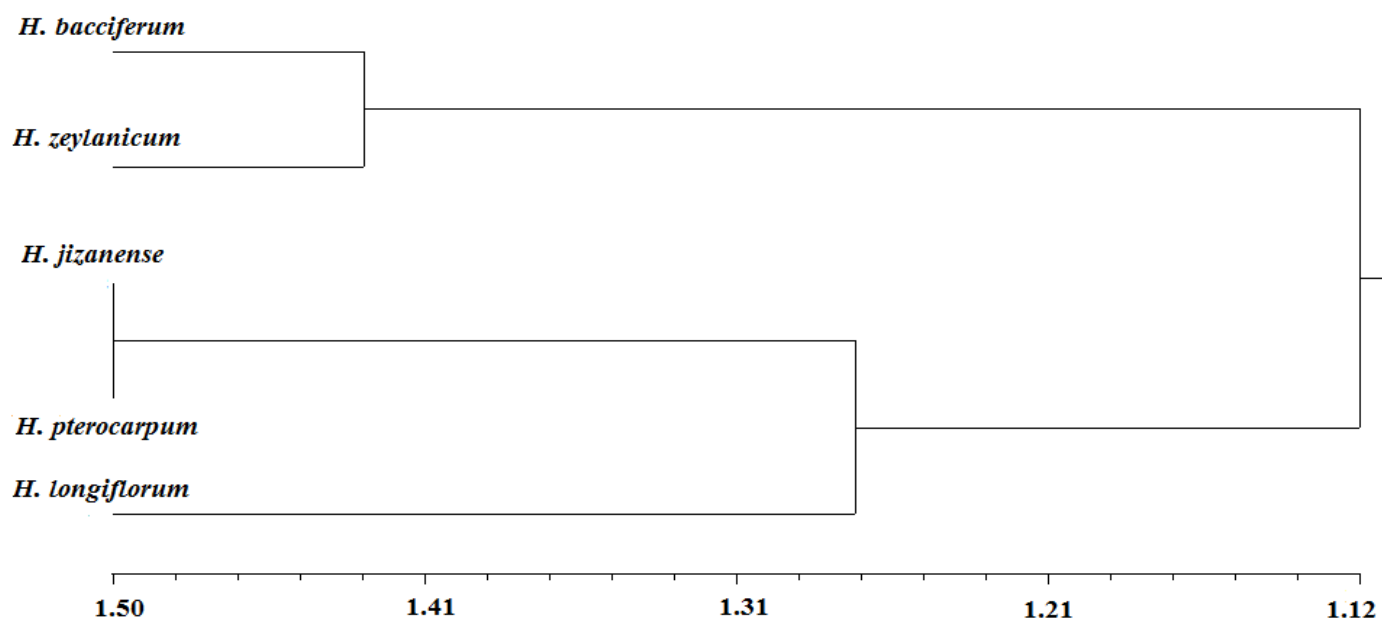

Figure (2): Phenogram of five studied Heliotropium species for morphological and phytochemical analyses 
Table (2): Tabular summary showing the morphological characters for the studied species.

\begin{tabular}{|c|c|c|c|c|c|c|}
\hline Species & Paramter & 1 & 2 & 3 & 4 & 5 \\
\hline \multirow[t]{2}{*}{ I- Habit } & a- growth & 1 & 1 & 1 & 1 & 1 \\
\hline & b- life cycle & 1 & 0 & 0 & 0 & 1 \\
\hline \multirow[t]{5}{*}{ II- Stem } & a- hair type & 1 & 1 & 0 & 1 & 1 \\
\hline & $\begin{array}{l}\text { b- hair } \\
\text { direction }\end{array}$ & 1 & 1 & 0 & 1 & 0 \\
\hline & $\begin{array}{l}\text { c- hair } \\
\text { density }\end{array}$ & 0 & 0 & 1 & 0 & 0 \\
\hline & d- stem type & 1 & 1 & 1 & 1 & 1 \\
\hline & $\begin{array}{l}\text { e- growth } \\
\text { form }\end{array}$ & 0 & 1 & 1 & 0 & 1 \\
\hline \multirow[t]{8}{*}{ III- Leaves } & a- blade & 1 & 0 & 1 & 1 & 1 \\
\hline & b- margin & 0 & 0 & 1 & 0 & 1 \\
\hline & c- length & 0 & 1 & 1 & 0 & 1 \\
\hline & d- color & 1 & 1 & 1 & 1 & 0 \\
\hline & e- petiole & 1 & 1 & 1 & 1 & 1 \\
\hline & f- apex & 1 & 0 & 1 & 1 & 1 \\
\hline & g- leaf base & 1 & 1 & 0 & 1 & 0 \\
\hline & $\begin{array}{l}h \text { - leaf } \\
\text { arrangement }\end{array}$ & 1 & 1 & 1 & 1 & 1 \\
\hline IV- & a- cymes & 0 & 0 & 0 & 1 & 0 \\
\hline \multirow[t]{6}{*}{ Inflorescence } & b- length & 0 & 0 & 1 & 0 & 1 \\
\hline & $\begin{array}{l}\text { c- number of } \\
\text { flowers }\end{array}$ & 0 & 0 & 1 & 0 & 1 \\
\hline & $\begin{array}{l}\text { d- flower } \\
\text { pedicel }\end{array}$ & 0 & 0 & 0 & 0 & 0 \\
\hline & $\begin{array}{l}\text { e- flower } \\
\text { bracts }\end{array}$ & 0 & 0 & 0 & 0 & 0 \\
\hline & f- calyx lobes & 0 & 0 & 0 & 1 & 0 \\
\hline & $\begin{array}{l}\text { g- corolla } \\
\text { color }\end{array}$ & 1 & 1 & 1 & 1 & 0 \\
\hline \multirow[t]{3}{*}{ V- Fruit } & a- type & 0 & 0 & 1 & 1 & 1 \\
\hline & $\begin{array}{l}\text { b- number of } \\
\text { nutlets }\end{array}$ & 1 & 0 & 1 & 0 & 1 \\
\hline & $\begin{array}{l}\text { c- nutlet } \\
\text { margin }\end{array}$ & 0 & 0 & 0 & 1 & 0 \\
\hline
\end{tabular}

I- Habit: (a- growth: 0= non-herb, 1= herb; b- Life cycle: $0=$ annual, 1= perennial), II- Stem: (a- hair type: $0=$ wooly, $1=$ bristly; $b$ - hair direction: $0=$ appressed, $1=$ erect; $c$ - hair density: $0=$ sparse, $1=$ densely; $d$ - stem type: $0=$ non-terete, $1=$ terete; $\mathrm{e}$ - growth form: $0=$ ascending, $1=$ erect), III- Leaves: (ablade: $0=$ elliptic, $1=$ lanceolate; $b$ - margin: $0=$ undulate to crenate, $1=$ entire; c- length: $0=$ short, $1=$ long; $d$ - color: $0=$ greenish yellow, $1=$ green; e- petiole: $0=$ sessile, $1=$ petiolate; $f-$ apex: $0=$ obtuse, $1=$ acute; $g$ - leaf base: $0=$ cuneate, $1=$ attenuate; $h$ - leaf arrangement: $0=$ non-alternate, $1=$ alternate), IVInflorescence: (a- cymes: $0=$ weakly scorpioid, $1=$ Strongly scorpioid; blength: $0=$ short terminal, $1=$ long terminal; $\mathrm{c}$ - number of flowers: $0=$ slightly dense, $1=$ dense; $\mathrm{d}$ - flower pedicel: $0=$ absent, $1=$ present; $\mathrm{e}$ - flower bracts: $0=$ ebracteate $1=$ bracteates; $\mathrm{f}$ - calyx lobes: $0=$ polysepalous, $1=$ synsepalous; $\mathrm{g}$ corolla color: $0=$ yellow, $1=$ white), $\mathrm{V}$ - Fruit: (a- type: $0=$ hairy nutlets $1=$ glabrous nutlets; $b$ - number of nutlets: $0=$ two, $1=$ four; $c$ - nutlet margin: $0=$ non-winged $1=$ winged).

Species: (1- H. bacciferum, 2- H. jizanense, 3- H. longiflorum, 4- $H$.

pterocarpum, 5- H. zeylanicum).

\section{Photosynthetic pigments contents}

Variable contents of photosynthetic pigments were observed among different species of Heliotropium. It was found that, the highest content of pigments was recorded in $H$. zeylanicum. On the other hand, $H$. bacciferum showed the lowest contents of pigments. In details, the contents of chl. a, Chl. b and carotenoids in $H$. bacciferum were lower than by $83 \%, 90 \%$ and $65 \%$ of the corresponding in $H$. zeylanicum, respectively. The pigments contents of $H$. jizanense and $H$. pterocarpum were noticed to be almost similar in all fractions. H. longiflorum was found to contain rationally medium pigment concentrations among all species in this study. Moreover, chlorophylls $(\mathrm{a}+\mathrm{b})$ confirmed the variability of species when the sum was compared. The results revealed that, sum of Chl. a and Chl. b was higher in $H$. zeylanicum $(2.76 \mathrm{mg} / \mathrm{g} \mathrm{FW})$ when compared with that of $H$. longiflorum $(0.45 \mathrm{mg} / \mathrm{g} \mathrm{FW})$ which considered the lowest value. It was observed, both $H$. jizanense and $H$. pterocarpum recorded similar values of Chl. $(\mathrm{a}+\mathrm{b})$ they were 1.53 and $1.54 \mathrm{mg} / \mathrm{g} \mathrm{FW}$ respectively (Figure3).

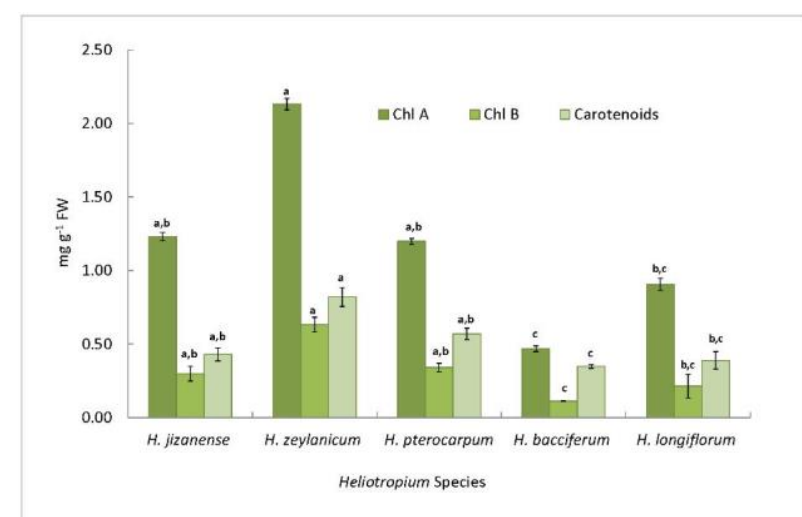

Figure (3): Photosynthetic pigments content (chlorophyll A, chlorophyll Bcarotenoids) ( $\mathrm{mg} \mathrm{g}^{-1} \mathrm{FW}$ ) of different Heliotropium species.

\section{Soluble, insoluble and total proteins content}

From the obtained results, proteins content (soluble, insoluble and total) were noticed to be variable among Heliotropium species. A wide range of variation was detected between $H$. zeylanicum and $H$. jizanense in all protein fractions. In details, $H$. zeylanicum recorded the highest values of soluble, insoluble and total proteins they were 23.25, 234.61 and $257.87 \mathrm{mg} / \mathrm{g} \mathrm{DW}$, respectively. On the other hand, H. jizanense recorded the lowest values $9.24,94.63$ and $103.87 \mathrm{mg} / \mathrm{g} \mathrm{DW}$ for soluble, insoluble and total proteins, respectively. Protein contents of both $H$. pterocarpum and $H$. longiflorum were found to be similar in all protein fractions. $H$. bacciferum was observed to have medium values of soluble, insoluble and total proteins compared with the values of other collected species (Figure4).

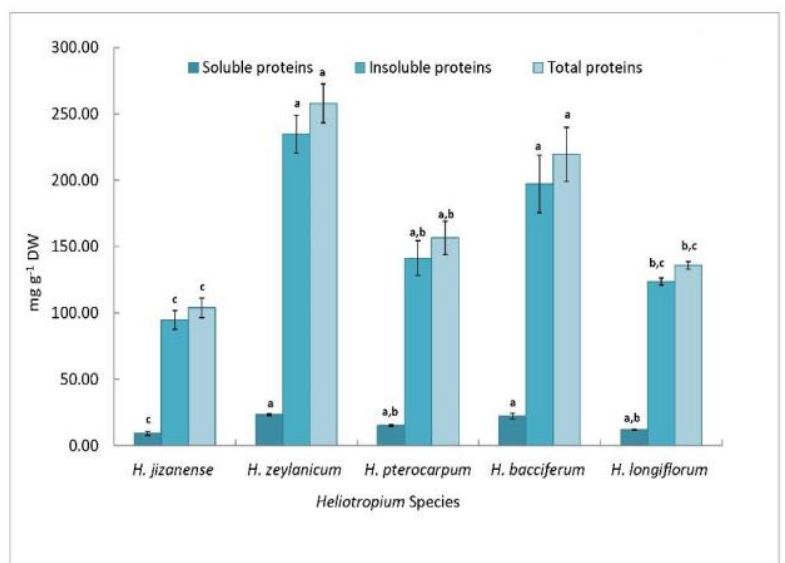

Figure (4): Protein content (soluble, insoluble and total) ( $\left.\mathrm{mg} \mathrm{g}^{-1} \mathrm{FW}\right)$ of different Heliotropium species. 


\section{Total phenolic compounds contents}

A clear variation in contents of phenolic compounds was detected in the five different species of Heliotropium. Figure (5) presents the analysis of phenolic compounds contents which appear to follow the same manner as previously described parameters; pigments and proteins. The highest content of phenolic compounds was recorded in $H$. zeylanicum $(66.50 \mu \mathrm{g} \mathrm{GAE} / \mathrm{g}$ DW) followed by $H$. bacciferum $(58.06 \mu \mathrm{g} \mathrm{GAE} / \mathrm{g}$ DW). Moreover, the lowest content was detected in $H$. jizanense (11.46 $\mu \mathrm{g} \mathrm{GAE} / \mathrm{gDW})$ and $H$. longiflorum (16.66 $\mu \mathrm{g} \mathrm{GAE} / \mathrm{g}$ DW). Comparing the ratios of contents of phenolic, the results demonstrated presence of almost 6 times phenolics in $H$. zeylanicum more than $H$. jizanense and 4 folds more than that detected in $H$. longiflorum. The arrangement of amounts of phenolic compounds present in different species followed this relation; $H$. zeylanicum $>H$. bacciferum $>H$. pterocarpum $>H$. longiflorum $>H$. jizanense.

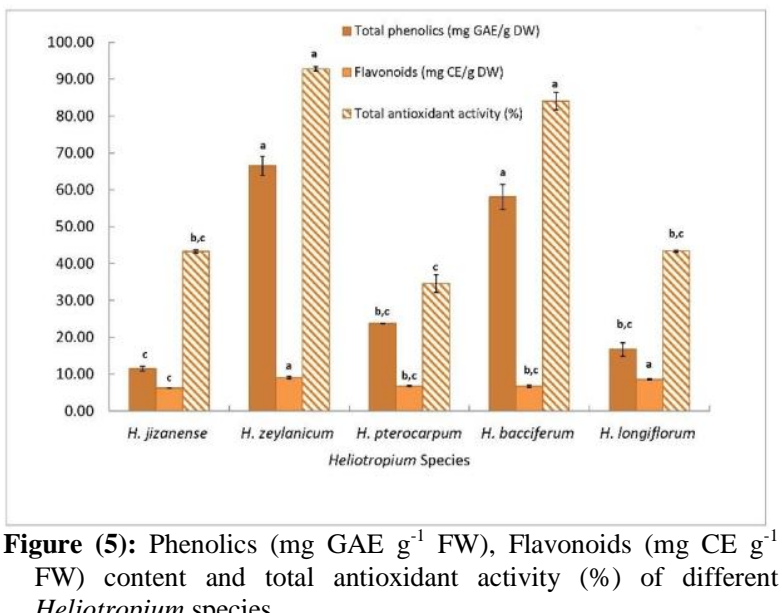

\section{Total Flavonoids contents}

The variation of flavonoids content among compared species of Heliotropium was obvious. Three of the species showed almost similar flavonoids content they were $\mathrm{H}$. pterocarpum, $\mathrm{H}$. bacciferum and $\mathrm{H}$. jizanense. The species $\mathrm{H}$. zeylanicum contained the highest amount $(9.09 \mu \mathrm{g} \mathrm{CE} / \mathrm{g}$ DW). Similar amounts of flavonoids were detected in both $\mathrm{H}$. zeylanicum and $\mathrm{H}$. longiflorum. Concentration of flavonoids in $\mathrm{H}$. zeylanicum was almost 1.5 fold of $\mathrm{H}$. jizanense (46\% higher) and 1.3 higher than $\mathrm{H}$. zeylanicum and $\mathrm{H}$. pterocarpum (35\% higher). H. longiflorum contained flavonoids with percentage $93 \%$ content of that detected in H. zeylanicum (Figure 5).

\section{Total antioxidant activity}

The analysis of total antioxidant activity of extracts from different Heliotropium species showed noticeable variation. The variation was slightly in accordance with the contents of phenolics and flavonoids. The antioxidant activity was calculated as percentages. From the obtained results, the most obvious antioxidant activity was recorded in $H$. zeylanicum species where the percentage reached $92.79 \%$. Similarly, species $H$. bacciferum recorded high antioxidant activity of about $84.08 \%$. Among the analysed species there were two species had lower antioxidant activity and nearly the same; they were $H$. longiflorum (43.37\%) and $H$. jizanense (43.29\%). On the other hand, H. pterocarpum had the lowest antioxidant activity (34.54\%) among the analysed species. The percentage in case of $H$. pterocarpum reached one third of the antioxidant activity of $H$. zeylanicum. Moreover, the antioxidant activity of $H$. jizanense extract was half of that detected in $H$. bacciferum. Large differences in antioxidant activities among the five collected species should be taken into consideration (Figure 5).

Table (3): Similarity matrix of studied Heliotropium species for morphological and phytochemical analyses.

\begin{tabular}{lccccc}
\hline \hline $\begin{array}{c}\text { Heliotropium } \\
\text { species }\end{array}$ & H.bacciferum & H.jizanense & H.longiflorum & H.pterocarpum & H.zeylanicum \\
\hline H.bacciferum & 1 & & & & \\
H.jizanense & 0.56 & 1 & & & \\
H.longiflorum & 0.41 & 0.44 & 1 & & \\
H.pterocarpum & 0.59 & 0.59 & 0.41 & 1 & 1 \\
H. zeylanicum & 0.59 & 0.38 & 0.62 & 0.32 & 1 \\
\hline \hline
\end{tabular}

\section{DISCUSSION}

The output of SAHN-clustering program was presented in the form of a phenogram by using the tree display graph. The phenogram, Figure (2), showed that the studied species have an average taxonomic distance of 0.88. At this level, H. jizanense is separated from other species. The remaining species are differentiated into two clusters at a distance of about 1.08 where the first cluster, $H$. pterocarpum is split off as a delimited group. $H$. bacciferum and $H$. longiflorum are grouped together in the second cluster at about 1.12. Based on the above results, high similarity indices suggest that the species have close genetic relationship among them (Hasan et al., 2009). (Table 3) shows similarity indices between the five species where the high value indicated a close relationship between the two species and the low value indicated remote relationships between the two species. The highest similarity value $(0.62)$ was recorded between $H$. longiflorum and $H$. zeylanicum indicating that these two species were closely related to each other. On the other hand, the lowest similarity value (0.32) was recorded between $H$. pterocarpum and $H$. zeylanicum indicating that these were distantly related species.

The analyses of photosynthetic pigments, proteins, 
antioxidant compounds as well as antioxidant activity of extracts of different Heliotropium species confirmed the previously obtained results and indications. There is characterized difference in contents of Photosynthetic pigments among species; $H$. zeylanicum contained rationally high content of pigments, two species were almost similar in pigments content they were $H$. jizanense and $H$. pterocarpum and the lowest content of pigments was detected in $H$. bacciferum. The comparison based of each pigment fraction in all studied species. To confirm; the total pigment content in each species was obviously different. Results demonstrated that $H$. zeylanicum contained $3.58 \mathrm{mg} / \mathrm{g} \mathrm{FW}$ while $H$. bacciferum contained $0.93 \mathrm{mg} / \mathrm{g} \mathrm{FW}$. In other words where $H$. zeylanicum contained almost 4 folds of pigments contained by $H$. bacciferum; a large difference cannot be ignored. Other species such as H. jizanense and $H$. pterocarpum contained almost half amount of pigments of $H$. zeylanicum. Previously, chlorophyll content was used to differentiate between genetically different Acacia species (Mathura et al., 2006). Moreover, physiological measurements inclu-ding leaf nitrogen and chlorophyll content were used to differentiate 17 oak species (Cavender-Bares et al., 2004).

The concentration of soluble, insoluble and total proteins was found to be distinctly different among the studied Heliotropium species. Similar to pigments analysis of the collected species; the highest content of proteins was detected in $H$. zeylanicum. It seems that both $H$. zeylanicum and $H$. bacciferum were closely related; they have nearly similar protein content. In addition, two of the studied species were also found to be closely related on basis of protein content; they were $H$. pterocarpum and $H$. longiflorum. Lowest protein content was recorded in $H$. jizanense in relation to other species in this study. Previous study used variation of protein content and protein profiles to differentiate 52 finger millet Eleusine coracana genot-ypes. Moreover, protein analysis used to define genetic relationship among twelve species of Ipomea (Das and Mukherjee 1995).

Phenolics and flavonoids present in clearly variable amounts in the studied Heliotropium species. Similar to that of protein content; the variation of phenolics as well as flavonoids content followed the same manner among the analyzed species. This means, H. zeylanicum recorded the highest phenolics and flavonoids values while $H$. jizanense had the lowest ones in relation to other values of the tested species. Based on their phenolics content, both species $H$. zeylanicum and $H$. bacciferum had higher amounts while species $H$. jizanense and $H$. longiflorum had lower but not lowest amounts of phenolics indicating members of each pair of species is closely related. On the other hand, the highest amount of flavonoids was detected in $H$. zeylanicum $(9.09 \mu \mathrm{g} \mathrm{CE} / \mathrm{g} \mathrm{DW})$ and the lowest present in H. pterocarpum (6.71 $\mu \mathrm{g} \mathrm{CE} / \mathrm{g} \mathrm{DW})$. It was noticed similarity in flavonoids content between $H$. pterocarpum and $H$. bacciferum. It was reported, the quantitative analysis of phenolics and flavo-noids as well as the antioxidant activity of methanolic extracts was used to compare six species of Salvia (Asadi et al., 2010).
Moreover, a comparative study for flavonoids was done to differentiate species belonging to Brassicaceae, two species of Scutellaria and species of Astragalus (Krasteva et al., 2016).

Detection of antioxidant activity of extracts of the studied Heliotropium species revealed obvious difference. From the results, it seems that the antioxidant activity was directly proportional with their content of phenolics. In other words, the higher phenolic content caused higher the antioxidant activity. Both $H$. zeylanicum $(92.79 \%)$ and $H$. bacciferum $(84.08 \%)$ had antioxidant activities higher than that of $H$. longiflorum (43.37\%) and H. jizanense (43.29\%). H. pterocarpum had the lowest antioxidant activity $(34.54 \%)$. Based on the analysis of antioxidant activity of the five species there were relationship between $H$. zeylanicum and $H$. bacciferum as well as close relation between $H$. longiflorum and $H$. jizanense. In previous reports, total antioxidant potential was used to differentiate resinous exudates of Heliotropium species (Modak et al., 2009), compare cherries species, Vaccinium species and Phyllanthus species (Kum-aran and Joel Karunakaran 2007).

Different habitat could directly affect the amounts of bioactive products accumulated in plants. AbdElGawad et al., (2019) compared phenolics content as well as the antioxidant activity of different Heliotropium species collected from coastal and inland habitats.

Recently, a similar comparison of 16 Heliotropium species collected from different regions of Turkey was done to investigate differences of leaf and stem anatomy of Turkish Heliotropium taxa. The study was used to show the taxonomic similarities between Heliotropium species on basis of their leaf and stem anatomy (Kandemir et al., 2020).

\section{REFERENCES}

ABD-ELGAWAD A.M., A.I. ELSHAMY, S.L. ALROWAILY AND Y.A. EL-AMIER. 2019. Habitat affects the chemical profile, allelopathy, and antioxidant properties of essential oils and phenolic enriched extracts of the invasive plant Heliotropium curassavicum. Plants 8 (11): 482.

ALFARHAN A.H., T.A. AL-TURKI AND A.Y. BASAHY. 2005. Flora of Jizan region. Final Report Supported by King Abdulaziz City for Science and Technology 1: 545.

ASADI S., A. AHMADIANI, M.A. ESMAEILI, A. SONBOLI, N. ANSARI AND F. KHODAGHOLI. 2010. In vitro antioxidant activities and an investigation of neuroprotection by six Salvia species from Iran: a comparative study. Food and chemical toxicology 48 (5): 1341-1349.

CAVENDER-BARES J., K. KITAJIMA AND F. BAZZAZ. 2004. Multiple trait associations in relation to habitat differentiation among 17 Floridian oak species. Ecological Monographs 74 (4): 635-662.

DAS S. AND K. MUKHERJEE. 1995. Comparative study on seed proteins of Ipomoea. Seed Science and Technology (Switzerland). 
DEWANTO V., X. WU, K.K. ADOM AND R.H. LIU. 2002. Thermal processing enhances the nutritional value of tomatoes by increasing total antioxidant activity. Journal of agricultural and food chemistry 50 (10): 3010-3014.

DUNCAN D.B. 1951. A significance test for differences between ranked treatments in an analysis of variance. Virginia Polytechnic Institute.

EL-GAZZAR A. AND S. RABEI. 2008. Taxonomic assessment of five numerical methods and its implications on the classification of Hyptis sl (Labiatae). International Journal of Botany 4 (1): 85-92.

GABR S., S. NIKLES, E.M. PFERSCHY WENZIG, K. ARDJOMAND-WOELKART, R.M. HATHOUT, S. EL-AHMADY, A.A. MOTAAL, A. SINGAB AND R. BAUER. 2018. Characterization and optimization of phenolics extracts from Acacia species in relevance to their anti-inflammatory activity. Biochemical Systematics and Ecology 78: 21-30.

Gower, J. C. (1982). Euclidean distance geometry. Math. Sci, 7, 1-14.

HASAN S.M.Z., M.S.B. SHAFIE AND R.M. SHAH. 2009. Analysis of random amplified polymorphic DNA (RAPD) of Artemisia capillaris (Wormwood capillary) in East Coast of Peninsular Malaysia. World Appl. Sci. J 6 (7): 976-986.

KANDEMIR N., A. ÇELIK, S.N. SHAH AND A. RAZZAQ. 2020. Comparative micro-anatomical investigation of genus Heliotropium (Boraginaceae) found in Turkey. Flora 262: 151495.

KRASTEVA I., A. SHKONDROV, I. IONKOVA AND P. ZDRAVEVA. 2016. Advances in phytochemistry, pharmacology and biotechnology of Bulgarian Astragalus species. Phytochemistry reviews 15 (4): 567-590.

KUMARAN A. AND R. JOEL KARUNAKARAN. 2007. In vitro antioxidant activities of methanol extracts of five Phyllanthus species from India. LWT - Food Science and Technology 40 (2): 344352.

LICHTENTHALER H.K. AND C. BUSCHMANN. 2001. Chlorophylls and carotenoids: Measurement and characterization by UV-VIS spectroscopy. Current protocols in food analytical chemistry.

LISSI E.A., B. MODAK, R. TORRES, J. ESCOBAR AND A. URZUA. 1999. Total antioxidant potential of resinous exudates from Heliotropium species, and a comparison of the ABTS and DPPH methods. Free Radical Research 30 (6): 471-477.

LOWRY O.H., N.J. ROSEBROUGH, A.L. FARR AND R.J. RANDALL. 1951. Protein measurement with the Folin phenol reagent. J biol Chem 193 (1): 265-275.

MATHURA S., A. FOSSEY AND S.L. BECK. 2006. Comparative study of chlorophyll content in diploid and tetraploid black wattle (Acacia mearnsii) Forestry 79 (4): 381-388.

MODAK B., M.L. CONTRERAS, F. GONZÁLEZNILO AND R. TORRES. 2005. Structureantioxidant activity relationships of flavonoids isolated from the resinous exudate of Heliotropium sinuatum. Bioorganic \& medicinal chemistry letters 15 (2): 309-312.

MODAK B., M. ROJAS AND R. TORRES. 2009 Chemical analysis of the resinous exudate isolated from Heliotropium taltalense and evaluation of the antioxidant activity of the phenolics components and the resin in homogeneous and heterogeneous systems. Molecules 14 (6): 1980-1989.

MYERS N., R.A. MITTERMEIER, C.G. MITTERMEIER, G.A. DA FONSECA AND J. KENT. 2000. Biodiversity hotspots for conservation priorities. Nature 403 (6772): 853.

NAGGAR S.E., A. EL-HADIDY AND A. OLWEY. 2015. Taxonomic revision of the genus Heliotropium (Boraginaceae sl) in south Yemen. Nordic Journal of Botany 33 (4): 401-413.

OGBOLE O., P. SEGUN AND P. FASINU. 2018. Antimicrobial and antiprotozoal activities of twenty-four Nigerian medicinal plant extracts. South African Journal of Botany 117: 240-246.

RICHARDSON A.D., S.P. DUIGAN AND G.P. BERLYN. 2002. An evaluation of noninvasive methods to estimate foliar chlorophyll content. New phytologist 153 (1): 185-194.

SANTOS L.D.T., M. THADEO, L. IAREMA, R.M.S.A. MEIRA AND F.A. FERREIRA. 2008. Foliar anatomy and histochemistry in seven species of Eucalyptus. Revista Árvore 32 (4): 769-779.

SELVI F. AND M. BIGAZZI. 2001. Leaf surface and anatomy in Boraginaceae tribe Boragineae with respect to ecology and taxonomy. Flora 196 (4): 269-285.

SHIMADA K., K. FUJIKAWA, K. YAHARA AND T. NAKAMURA. 1992. Antioxidative properties of xanthan on the autoxidation of soybean oil in cyclodextrin emulsion. Journal of agricultural and food chemistry 40 (6): 945-948.

SINGLETON V.L. AND J.A. ROSSI. 1965. Colorimetry of total phenolics with phosphomolybdicphospho-tungstic acid reagents. Am j Enology Viticult 16 (3): 144-158.

TRUGO L.C., D. VON BAER AND E. VON BAER 2003. LUPIN. In: CABALLERO, B. (ed.) Encyclopedia of Food Sciences and Nutrition (Second Edition). Academic Press.Oxford, England.

YAO Q., K. YANG, G. PAN AND T. RONG. 2007. Genetic diversity of maize (Zea mays L.) landraces from Southwest China based on SSR data. Journal of genetics and genomics 34 (9): 851-860. 


\title{
تحليل مقارن لخمسه أنواع من الهليوتروبيوم في الارتباطات المظهريه، المكونات الكيمائيه الحيويه وخصائص مضادات الأكسده
}

\author{
ضياء الاين محم رضوان 1,2 وأحمد عيسي الثباسي1 \\ 1 قسم الاحياء، كليه العلوم، جامعه جاز ان، الدملكه العربيه السعوديه

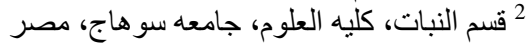 \\ الملخص العربـــي
}

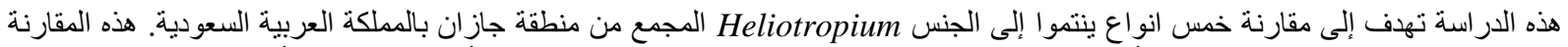

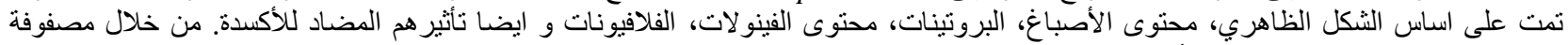

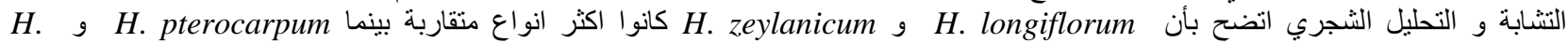

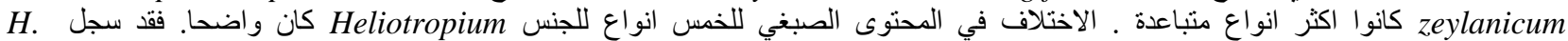

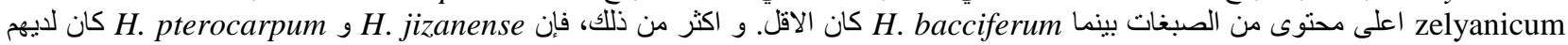

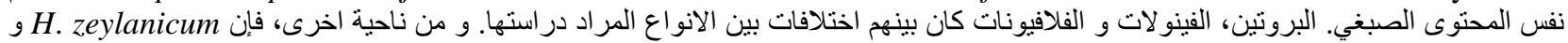

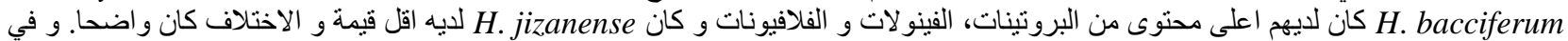

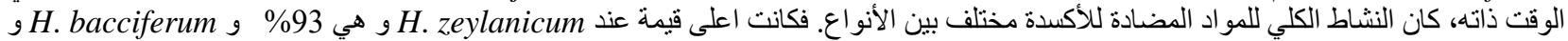
هي 84\% بينما 